\title{
EVIDENCE-BASED USE OF SEA BUCKTHORN FRESH JUICE FOR PATIENTS WITH TRAUMATIC BRAIN INJURY. A PILOT STUDY
}

\author{
CONSTANTIN SORIN GODEANU ${ }^{1}$, TEODORA COSTEA ${ }^{2 *}$, MANUELA GHICA $^{2}$, DUMITRU \\ LUPULIASA ${ }^{2}$, CERASELA ELENA GÎRD ${ }^{2}$ \\ ${ }^{1}$ Department of Anaesthesia and Intensive Care Unit, "Floreasca” Emergency Clinical Hospital, 014461, Bucharest, Romania \\ 2 "Carol Davila” University of Medicine and Pharmacy, Faculty of Pharmacy, 020956 Bucharest, Romania
}

*corresponding author: teodora.costea@umfcd.ro

Manuscript received: October 2019

\begin{abstract}
Sea buckthorn (Hippophä̈ rhamnoides L.) berries are widely used for their nutrional value and therapeutic effects. The aim of our paper was the evolution of phenolic content (by means of spectrophotometric methods), antioxidant capacity (scavenger activity towards DPPH, ABTS + free radicals and ferric reducing power) and evidence regarding sea buckthorn fresh juice association in the management of hospitalized patients with traumatic brain injury. According to our results, sea buckthorn fresh juice is a source of phenolic compounds $(0.28 \mathrm{~g}$ total phenolic content expressed as tannic acid equivalents $/ 100 \mathrm{~mL}$ fresh juice and $0.09 \mathrm{~g}$ flavones expressed as hyperoside equivalents $/ 100 \mathrm{~mL}$ fresh juice), with antioxidant activity. Our clinical results have shown beneficial effects (a decrease in lactate and sodium blood levels and an increase in Glasgow coma score) of sea buckthorn fresh juice (given together with specific medication) in the management of patients with traumatic brain injury.
\end{abstract}

\section{Rezumat}

Fructele de cătină (Hippophaë rhamnoides L.) sunt întrebuințate atât pentru aportul nutrițional cât și datorită efectelor terapeutice variate. Scopul lucrării a constat în evaluarea conținutului în compuși fenolici (prin metode spectrofotometrice), a activității antioxidante (chelatarea radicalilor liberi DPPH, ABTS ++, capacitatea de reducere a ferului) și a beneficiilor terapeutice ale sucului de cătină la pacienți spitalizați cu neurotraumă. Rezultatele obținute au arătat că sucul de cătină e ste o sursă de polifenoli $(0,28 \mathrm{~g}$ polifenoli totali exprimaţi în echivalenţi de acid tanic/100 mL suc şi $0,09 \mathrm{~g}$ flavone exprimate în echivalenți de hiperozidă/100 mL suc), cu efect antioxidant. Rezultatele clinice au arătat o îmbunătățire a stării de sănătate (scăderea concentrațiilor serice de sodiu și lactat, creșterea scorului Glasgow) a pacienților cu neurotraumă, la care s-a administrat pe lângă medicația specifică și sucul de cătină.

Keywords: sea buckthorn berry juice, polyphenols, antioxidant capacity, traumatic brain injury

\section{Introduction}

Traumatic brain injury (TBI) represents one of the most serious public health problems worldwide, accounting for $10 \%$ of the world's deaths [24]. Moreover, neurotrauma is suspected to contribute to neurodegenerative diseases, chronic traumatic encephalopathy, epileptic seizures or post traumatic diabetes $[1,5,11]$. Recent researches have shown that almost $51 \%$ of patients with TBI suffer of electrolyte imbalances and the mortality rates are higher for patients with hypernatremia [2, $16,19]$. Hypernatremia leads to an increase in extracellular osmolarity (beyond $280 \mathrm{mOsmol} / \mathrm{kg}$ ) and further activation of osmoreceptors in the hypothalamus. Activation of osmoreceptors favours the release of antidiuretic hormone and arginine, which in turn increase the reabsorption of water in the distal tubule and collecting duct [11]. Moreover, TBI patients have increased blood and cephalorachidian lactate levels, which are correlated to brain injuries severity [27]. It is well known that physiological increased lactate levels trigger reperfusion of ischemic brain tissues after TBI [29]. However, severe TBI leads to neuronal death, which in turn accounts for high lactate levels, which become an unfavourable prognostic factor [15, 20,22]. According to recent studies natural compounds (mainly polyphenols) positively influence several events involved in TBI (neuroinflammation, apoptosis, oxidative stress etc.) [13, 21, 28].

Sea buckthorn (Hippophaë rhamnoides L.) berries are a source of bioactive compounds with a wide range of therapeutic effects (hypocholesterolemic, hypoglycaemic, antioxidant, anti-inflammatory, etc.) $[4,12,14,23,25,31]$.

Taking into consideration the scientific data, the aim of our research was the evaluation of phenolic content, antioxidant capacity and evidence regarding sea buckthorn fresh juice association in the management of patients with TBI. 


\section{Materials and Methods}

\section{Materials}

Sea buckthorn juice (SSBJ) was obtained from fresh ripe fruits, collected in September 2018, from Prahova County, Romania. Juice extraction was performed at room temperature with an electric juice extractor (Philips HR18701/70, Netherlands).

All chemicals were purchased from Sigma-Aldrich and used without further purification.

Spectrophotometric determination of total phenolic content

Total phenolic content was determined by FolinCiocâlteu method, as previously described $[6,10]$. Results were expressed as g tannic acid/100 mL SBBJ, based on a calibration curve $\left(2-9 \mu \mathrm{g} / \mathrm{mL}, \mathrm{R}^{2}=0.999\right.$, $\mathrm{n}=8$ ).

Spectrophotometric determination of flavones content Flavones were determined based on their reaction with aluminium chloride as previously described [10]. Results were expressed as g hyperoside/100 mL SBBJ, based on a calibration curve $(7-34 \mu \mathrm{g} / \mathrm{mL}$, $\mathrm{R}^{2}=0.999, \mathrm{n}=12$ ).

Determination of antioxidant capacity

The antioxidant capacity was evaluated by means of scavenger activity towards 2,2-diphenyl-1-picrylhydrazyl (DPPH), 2,2'-azinobis-(3-ethylbenzothiazoline6-sulfonic acid) (ABTS + ) free radicals and ferric reducing power, as previously described $[6,10]$. The concentration range was 0.6 - $12 \mu \mathrm{L}$ SBBJ (for DPPH and ferric reducing power assays) and 0.6 - $6 \mu \mathrm{L} \mathrm{SBBJ}$ (for $\mathrm{ABTS}^{\circ}+$ assay). The antioxidant activity was expressed as $\mathrm{EC}_{50}(\mu \mathrm{L})$, which represents the SBBJ concentration that inhibits with $50 \%$ the activity of DPPH/ABTS + free radicals or the SBBJ concentration providing 0.5 absorbance (for ferric reducing power). The antioxidant activity was also expressed as ascorbic acid equivalents (mM ascorbic acid/100 mL SBBJ), based on vitamin $\mathrm{C}$ calibration curves: $0.005-0.04$ $\mathrm{mg} / \mathrm{mL}, \mathrm{R}^{2}=0.9975, \mathrm{n}=5$ (DPPH method); 0.01 $0.07 \mathrm{mg} / \mathrm{mL}, \mathrm{R}^{2}=0.9973, \mathrm{n}=6\left(\right.$ ABTS $^{\circ}+$ method $)$ and $0.008-0.04 \mathrm{mg} / \mathrm{mL}, \mathrm{R}^{2}=0.9969, \mathrm{n}=5$ (ferric reducing power).

Experimental protocol for SBBJ administration to TBI patients

Neuronal resuscitation protocol ("Floreasca" Emergency Hospital, Bucharest, Romania protocol) was used for SBBJ administration to TBI patients, hospitalized in the Anaesthesia and Intensive care unit (NCH-STI). Patients were divided into two groups. The control group consisted of five patients that received only common medication. The treatment group consisted of 26 TBI patients that received SBBJ besides common medication. Patients were given (by nasogastric intubation) $10 \mathrm{~mL} \mathrm{SBBJ} / \mathrm{kg}$ bw/day in the morning (8.30 - 10.30 a.m.). The patients did not receive food two hours before and after administration of SBBJ. Patients were monitored for 20 days, regarding their blood sodium/ lactate levels (which were determined in the hospital's laboratory) and Glasgow coma score. The clinical protocol was approved by the Local Medical Ethics Committee of "Floreasca" Emergency Hospital. An informed consent form was signed prior to administration of SBBJ by patients' family members.

Statistical analysis

Spectrophotometric and antioxidant assays were carried out in triplicate. Results are presented as mean \pm standard deviation (SD) and were determined in Microsoft Office (Excel, 2010). The statistical analysis for clinical data was performed using the open source software R. The data set was longitudinal and its main purpose was to characterize the changes observed over time (20 days) in three continuous response variables: blood sodium levels, blood lactate levels and Glasgow coma score. It was also important to highlight the main differences between control and treatment groups. As the conditions of normality and homoscedasticity were partially fulfilled, a robust method for two-way repeated measures ANOVA based on the trimmed means has been used [17]. We have also applied post hoc comparisons based on a single effect which uses a bootstrap approach $[8,9]$. Moreover, in the statistical analysis we followed the evolution of the Glasgow median score in relation to the average values of the two parameters (blood sodium lactate levels over 20 days), using Pearson coefficient, because the assumption of bivariate normality of residuals was fulfilled. A value of $p<0.05$ was considered the threshold for a statistically significant difference.

\section{Results and Discussion}

As shown in Table I, SBBJ is a source of phenolic compounds. Our results regarding the total phenolic content are similar to Tian Ye et al. that found 20.5 $25.5 \mathrm{mg}$ gallic acid/100 mL fresh juice (equivalent to $0.2049-0.2499 \mathrm{mg}$ tannic acid/100 $\mathrm{mL}$ fresh juice) [26], but much lower compared to Mendelova A et al. that found $2-2.92 \mathrm{~g}$ gallic acid/1 L of fresh juice (equivalent to 1.99 - $2.91 \mathrm{~g}$ tannic acid/100 $\mathrm{mL}$ fresh juice) [18]. Our flavones content is moderate, but a comparison with other authors' results was difficult, since most studies report the flavones content only for freeze-dried berries [12].

Our results regarding the antioxidant activity, showed that SBBJ has the ability to scavenge DPPH, ABTS ${ }^{*}$ free radicals and ferric reducing power properties. The scavenger activity towards DPPH varied between $29.11 \%$ (for $0.6 \mu \mathrm{L}$ ) and $85.07 \%$ (for $12 \mu \mathrm{L}$ ). The results are higher, compared to Tian Ye et al. that only found 29 - 31\% inhibition [26]. Regarding the ABTS $^{\circ}$ assay, SBBJ scavenged the free radical in a dose dependent manner; the highest inhibition (91.36\%) was achieved for $6 \mu \mathrm{L}$ fresh juice. The higher antioxidant activity towards ABTS + free radical, compared to DPPH, might be the consequence of a different 
mechanism of action. Concerning ferric reducing power, the highest absorbance $(0.5518)$ was found for the highest concentration ( $12 \mu \mathrm{L}$ fresh juice). As shown in table I, the highest antioxidant activity was observed using ABTS + assay, followed by DPPH and ferric reducing power methods. Important anti- oxidant activity for SBBJ was also reported by other authors [12, 14, 18, 23]. We assume that flavones [7], phenolcarboxylic acids [12], proanthocyanidins [31], carotenoids (mainly epoxide forms which are soluble in water) $[14,25]$ and mineral elements [4] are responsible for SBBJ overall antioxidant capacity.

Table I

Phenolic content and antioxidant activity of SBBJ

\begin{tabular}{|c|c|c|c|}
\hline \multicolumn{4}{|c|}{ SPECTROPHOTOMETRIC ASSAYS } \\
\hline $\begin{array}{l}\text { Total phenolic content } \\
\text { (g tannic acid/100 mL) }\end{array}$ & \multicolumn{3}{|c|}{$0.2895 \pm 0.0162$} \\
\hline $\begin{array}{c}\text { Flavones } \\
\text { (g hyperoside/100 mL) }\end{array}$ & \multicolumn{3}{|c|}{$0.0934 \pm 0.0104$} \\
\hline \multicolumn{4}{|c|}{ ANTIOXIDANT ASSAYS } \\
\hline Method & DPPH & ABTS $^{*}+$ & Ferric reducing power \\
\hline $\mathrm{EC}_{50}(\mu \mathrm{L})$ & $4.70 \pm 0.2687$ & $2.1250 \pm 0.1060$ & $11.66 \pm 0.1272$ \\
\hline $\begin{array}{l}\text { Ascorbic acid equivalents } \\
(\mathrm{mM} \text { ascorbic acid/100 mL) }\end{array}$ & $4.2732 \pm 3.3491$ & $19.5275 \pm 7.9394$ & $1.0748 \pm 0.0853$ \\
\hline
\end{tabular}

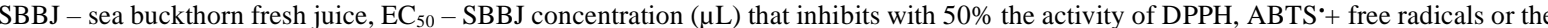
SBBJ concentration that provides 0.5 absorbance (for ferric reducing power) Results are expressed as mean \pm SD ( $n=3$ ).

Regarding our clinical results, for sodium blood levels response variable, one can note (Figure 1A) significant differences between groups $(\mathrm{p}=0.0049)$ and significant differences relative to time $(\mathrm{p}=0.002)$, but an insignificant interaction between time and group factors. Significant post hoc differences between groups were observed on days $1,3,4,7,8$ ( $p<0.05)$. For lactate blood levels response variable (Figure $1 \mathrm{~B})$, we observed significant differences between groups $(\mathrm{p}=0.00012)$ and significant differences relative to time factor $(\mathrm{p}=$ 0.002 ) and also a significant interaction between time and group factors $(\mathrm{p}=0.009)$. Significant post hoc differences between groups were observed on days $1,2,3,4,5,11,13,18,19,20$ ( $\mathrm{p}<0.05)$. For the Glasgow coma score response variable (Figure 1C) we obtained extremely significant differences between groups $(\mathrm{p}<0.0001)$ and significant differences regarding time factor $(\mathrm{p}=0.0011)$ and also a significant interaction between time and group factors $(p=0.0066)$. Significant post hoc differences between groups were observed during the whole period of SBBJ administration ( $\mathrm{p}<$ $0.003)$.

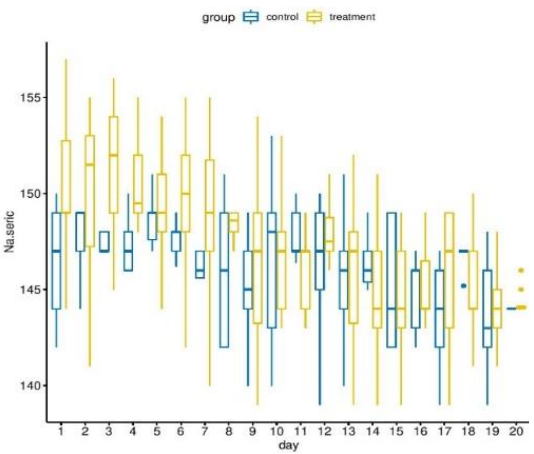

A

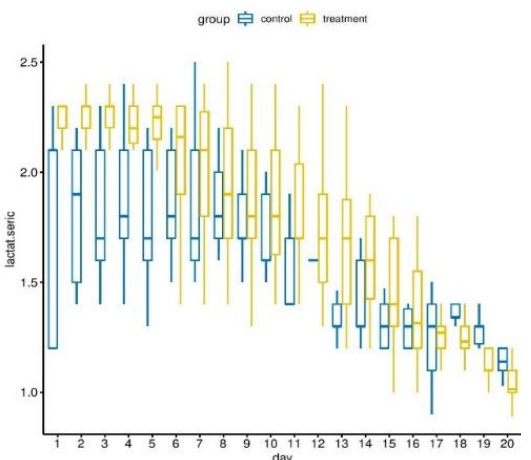

B

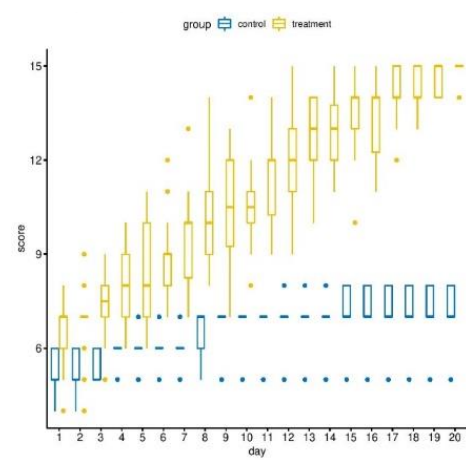

C

Figure 1.

Vi Evaluation of variables response for control and treatment groups A - blood sodium levels, B - blood lactate levels, C - Glasgow coma score

The average evolution of each response variable relative to time factor is highlighted for each analysed group (control/treatment) in Figure 2. As for our results (Figures 3 and 4), one can observe that the magnitude of the Pearson coefficient indicates an extremely high negative correlation (between Glasgow coma score and sodium/lactate blood levels) in the tested group (lactate blood levels $=-0.961$, CI 95\% $=(-0.98,-0.90)$ where $\mathrm{p}<0.0001$ and sodium blood levels $=-0.96$, CI $95 \%=(-0.98,-0.90)$ where $\mathrm{p}<0.0001)$ and $\mathrm{a}$ medium negative value in the control group (lactate blood levels $=-0.62$, CI 95\% $=(-0.83,-0.25)$ where $\mathrm{p}=0.003$ and sodium blood levels $=-0.68, \mathrm{CI} 95 \%=$ $(-0.86,-0.35)$ where $\mathrm{p}=0.008)$, interpretations given by guidelines of Cohen (Figure 3 ). The linear and quadratic regression functions that best estimate the dependency between the Glasgow coma score and lactate/sodium blood levels variables are presented in Figure 4. For the control group the adjusted r-squared values are relatively low: lactate blood levels explain 
$35.9 \%$ of Glasgow coma score variability $(\mathrm{p}=0.003)$, while sodium blood levels explain 44\% ( $\mathrm{p}=0.0008)$. For the treatment group the adjusted r-squared values are extremely high: lactate blood levels explain $92.5 \%$ of Glasgow coma score $(p<0.0001)$ and sodium

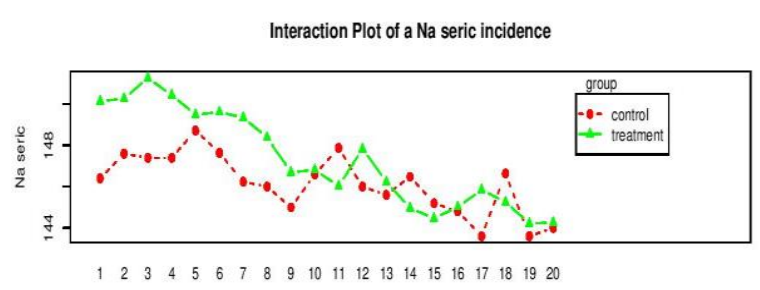

day

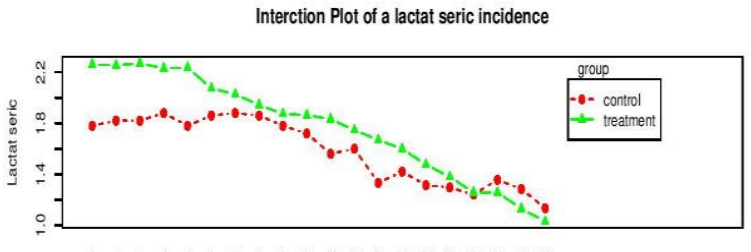

day

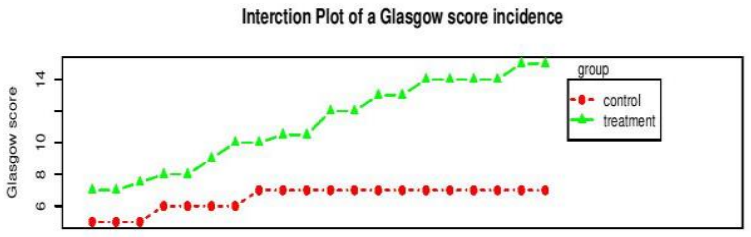

$\begin{array}{lllllllllllllllllllll}1 & 2 & 3 & 4 & 5 & 6 & 7 & 8 & 9 & 10 & 11 & 12 & 13 & 14 & 15 & 16 & 17 & 18 & 19 & 20\end{array}$

Figure 2.

Interaction of all variables (for control and treatment groups) relative to time factor

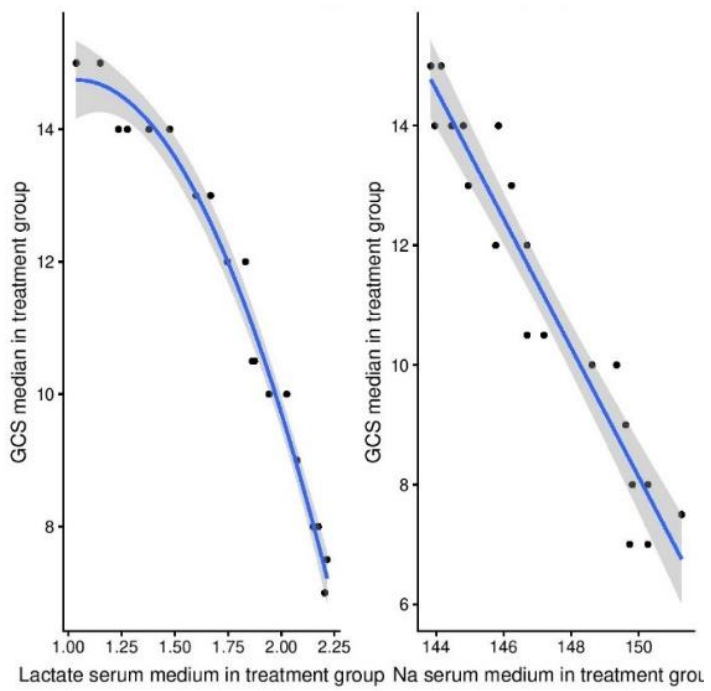

Figure 4.

V Variation of Glasgow coma score for analysed groups

We assume that polyphenols are responsible for SBBJ beneficial effects (decreased sodium and lactate blood
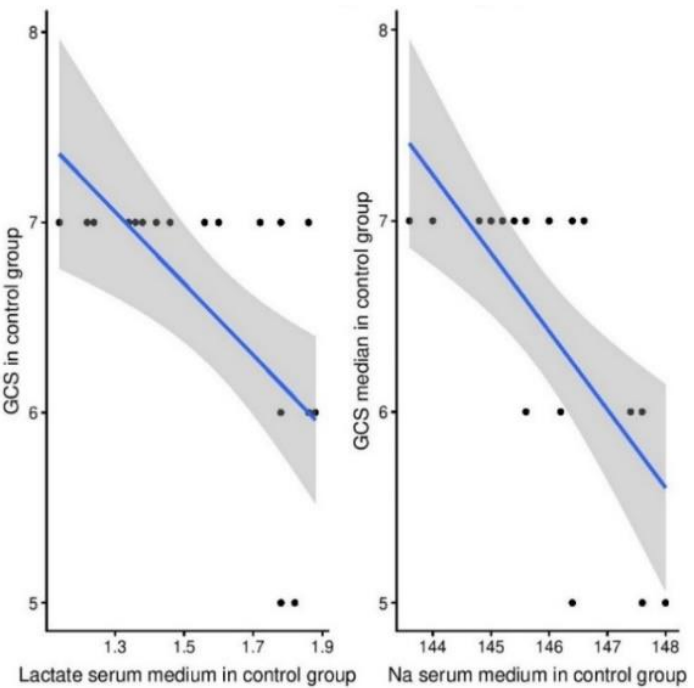

blood levels explain 91.8\% ( $<<0.0001)$. Residual normality, independence and homoscedasticity were fulfilled. The quadratic model was chosen based on the Akaike information criterion (AIC).

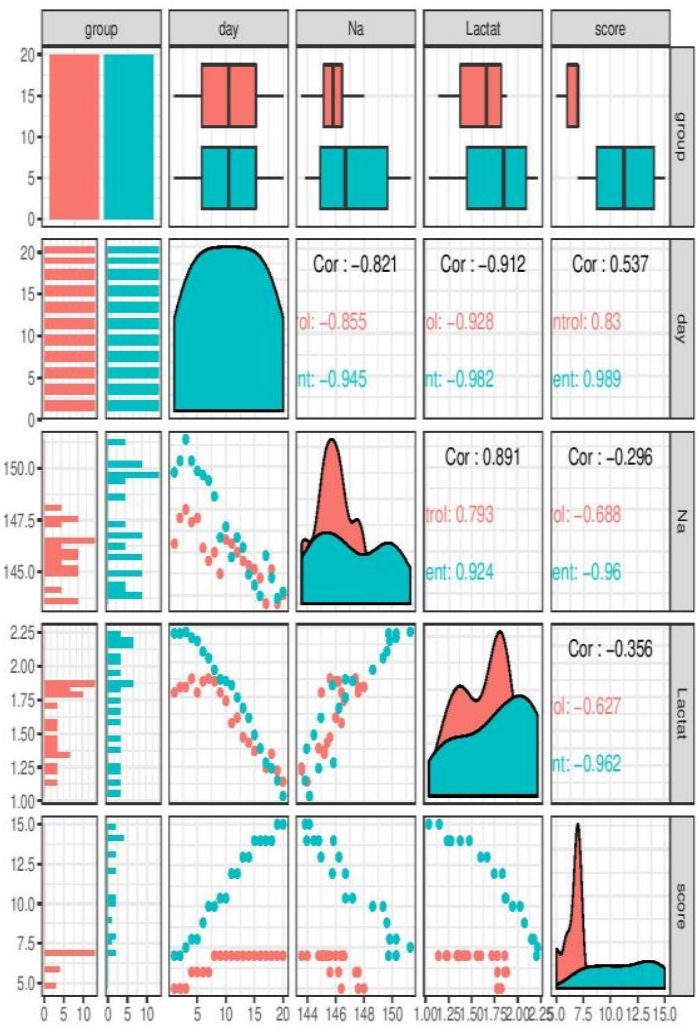

Figure 3.

Correlation between variables

Na serum medium in control group levels and increased Glasgow coma score) in patients with TBI. TBI involves hypoxia, cell death, mitochondrial 
dysfunction, oxidative stress, neuroinflammation and metabolic dysfunction [5].

According to recent research, flavones from sea buckthorn fresh juice (quercetin glycosides) [7] reduce the expression of Bax and cleaved caspase-3 proteins (involved in apoptosis), decrease the level of proinflammatory cytokines and increase the activity of antioxidant enzymes [30]. Kaempferol [7] was found to improve tricarboxylic acid cycle flux, neurons viability and mitochondrial integrity [13].

Among phenolcarboxylic acids found in sea buckthorn juice [12], chlorogenic acid has shown strong antiinflammatory effects in TBI, through down-regulation of TLR4 (toll-like receptor)/Nf-kb signalling pathways [3].

\section{Conclusions}

Sea buckthorn juice is a source of bioactive compounds, with antioxidant activity and beneficial effects (a decrease in lactate and sodium blood levels and an increase in Glasgow coma score) for hospitalized patients with traumatic brain injury.

\section{Conflict of interest}

The authors declare no conflict of interest.

\section{References}

1. Capatina C, Paluzzi A, Mitchell R, Karavitaki N, Diabetes insipidus after traumatic brain injury. $J$ Clin Med., 2015: 4(7): 1448-1462.

2. Chang $\mathrm{CH}$, Liao JJ, Chuang $\mathrm{CH}$, Lee CT, Recurrent hyponatremia after traumatic brain injury. Am J Med Sci., 2008; 335(5): 390-393.

3. Chen D, Pan D, Tang S, Tan Z, Zhang Y, Fu Y, Lu G, Huang Q, Administration of chlorogenic acid alleviates spinal cord injury via TLR4/NF- $\kappa \mathrm{B}$ and p38 signaling pathway anti-inflammatory activity. Mol Med Rep., 2018; 17(1): 1340-1346.

4. Christaki E, Hippophae rhamnoides L. (sea buckthorn): a potential source of nutraceuticals. Food and Public Health, 2012; 2(3): 69-72.

5. Corps KN, Roth TL, McGavern DB, Inflammation and neuroprotection in traumatic brain injury. JAMA Neurol., 2015; 72(3): 355-362.

6. Costea T, Vlase L, Istudor V, Gîrd CE, Popescu ML, Researches upon indigenous herbal products for therapeutic valorification in metabolic diseases. Note II. Polyphenols content, antioxidant activity and cytoprotective effect of Betulae folium dry extract. Farmacia, 2014; 62(5): 961-970.

7. Dong R, Su J, Nian H, Shen H, Zhai X, Xin H, Qin L, Han T, Chemical fingerprint and quantitative analysis of flavonoids for quality control of sea buckthorn leaves by HPLC and UHPLC-ESI-QTOF-MS. J Funct Foods, 2017; 37: 513-522.

8. Ghica M, Băncescu I, Udeanu DI, How we deal with small data?, Proceedings Of The Romanian National Congress Of Pharmacy, $17^{\text {th }}$ Edition: $21^{\text {st }}$ Century Pharmacy - Between Intelligent Specialization And Social Responsibility, 2018; 84-87.
9. Ghica M, Băncescu I, Udeanu DI, Tăerel A, Arsene AL, Anuța V, Velescu BȘ, Gherghiceanu F, Mititelu M, Ioniță CA, Computational approach for small data in animal models with induced metabolic disorders, Proceedings of $6^{\text {th }}$ International Conference on Interdisciplinary Management of Diabetes Mellitus and its Complications, INTERDIAB, 2020; 98-106.

10. Gîrd CE, Dutu LE, Costea T, Nencu I, Popescu ML, Balaci TD, Olaru OT, Research regarding obtaining herbal extracts with antitumor activity, Note II. Phytochemical analysis, antioxidant activity and cytotoxic effects of Chelidonium majus L., Medicago sativa L., Berberis vulgaris L. dry extracts. Farmacia, 2017; 65(5): 703-708.

11. Gritti P, Lanterna LA, Rotasperti L, Filippini M, Cazzangina C, Sarnecki T, Lorini FL, Clinical evaluation of hyponatremia and hypovolemia in critically ill adult neurologic patients: contribution of the use of cumulative balance of sodiu. J Anesth., 2014; 28: 687-695.

12. Guo R, Guo X, Li T, Fu X, Liu RH, Comparative assessment of phytochemical profiles, antioxidant and antiproliferative activities of Sea buckthorn (Hippophä rhamnoides L.) berries. Food Chem., 2017; 221: 997-1003.

13. Khalatbary AR, Natural polyphenols and spinal cord injury. Iran Biomed J., 2014; 18(3): 120-129.

14. Korekar G, Dolkar P, Singh H, Srivastava RB, Stobdan $\mathrm{T}$, Variability and the genotypic effect on antioxidant activity, total phenolics, carotenoids and ascorbic acid content in seventeen natural population of sea buckthorn (Hippophae rhamnoides L.) from transHimalaya. LWT-Food Sci. Technol., 2014; 55(1): 157-162.

15. Lama S, Auer RN, Tyson R, Gallangher CN, Tomanek $\mathrm{R}$, Sutherland G, Lactate storm marks cerebtal metabolism following brain trauma. J Biol Chem., 2014; 289: 20200-20208.

16. Maggiore U, Picetti E, Antonucci E, Perenti E, Regolisti G, Mergoni M, Vezzani A, Cabassi A, Fiaccadori E, The relation between the incidence of hypernatremia and mortality in patients with severe traumatic brain injury. Crit Care Med., 2009; 13: 1-9.

17. Mair P, Wilcox R, Robust statistical methods in $\mathrm{R}$ using the WRS2 package. Behav Res., 2019; 52: 464-488.

18. Mendelova A, Mendel L., Czako P, Mareck J., Evaluation of carotenoids, polyphenols content and antioxidant activity in the sea buckthorn fruit juice. Slovak $J$ Food Sci., 2016; 10(1): 59-64.

19. Paiva WS, Bezerra FDA, Amorim RLO, Figueiredo EG, Tavares WM, Andrade AF, Teixeira MJ, Serum sodium disorders in patients with traumatic brain injury. Ther Clin Risk Manag., 2011; 7: 345-349.

20. Pellerin L, Magistretti PJ, Glutamate uptake into astrocytes stimulates aerobic glycolysis: a mechanism coupling neuronal activity to glucose utilization. PNAS, 1994; 91(22): 10625-10626.

21. Rahimifard M, Maqbool F, Moeini-Nodeh S, Niaz K, Abdollahi M, Braidy N, Nabavi SF, Targeting the TLR4 signaling pathway by polyphenols: a novel therapeutic strategy for neuroinflammation. Ageing Res Rev., 2017; 36:11-19. 
22. Rice AC, Zsoldos R, Chen T, Wilison MS, Aleesandri B, Hamm RJ, Bullock MR, Lactate administration attenuates deficits following traumatic brain injury. Brain Res., 2002; 928(1-2): 156-159.

23. Rop O, Ercişli S, Mlcek J, Jurikova T, Hoza I, Antioxidant and radical scavenging activities in fruits of 6 sea buckthorn (Hippophae rhamnoides L.) cultivars. Turk J Agric For., 2014; 38(2): 224-232.

24. Rubiano AM, Carney N, Chesnut R, Puyana JC, Global neurotrauma research challenges and opportunities. Nature, 2015; 527(7578): S193-S197.

25. Teleszko M, Wojdyło A, Rudzińska M, Oszmiański $\mathrm{J}$, Golis T, Analysis of lipophilic and hydrophilic bioactive compounds content in sea buckthorn (Hippophae rhamnoides L.) berries. J Agric Food Chem., 2015; 63(16): 4120-4129.

26. Tian Y, Puganen A, Alakomi HL, Uusitupa A, Saarela $\mathrm{M}$, Yang B, Antioxidative and antibacterial activities of aqueous ethanol extracts of berries, leaves, and branches of berry plants. Food Res Int., 2018; 106: 291-303.

27. Unterberg AW, Stover J, Kress B, Kiening L, Edema and brain trauma. Neuroscience, 2004; 129(4): 1019-1027.
28. Uivaroşan D, Abdel-Daim MM, Endres L, Purza L, Iovan C, Bungău S, Furău CG, Ţiţ DM, Effects of a proteic swine extract associated to recovery treatment on functional independence and quality of life in patients post stroke. Farmacia, 2018; 66(5): 826830.

29. Won SJ, Jang BG, Yoo BH, Sohn M, Lee MW, Choi BY, Kim JH, Song HK, Suh SW, Prevention of acute/severe hypoglycemia-induced neuron death by lactate administration. J Cerebr Blood F Met., 2012; 32: 1086-1096.

30. Yang T, Kong B, Gu JW, Kuang YQ, Cheng L, Yang WT, Shu HF, Anti-apoptotic and anti-oxidative roles of quercetin after traumatic brain injury. Cell Mol Neurobiol., 2014; 34(6): 797-804.

31. Yang W, Laaksonen O, Kallio H, Yang B, Proanthocyanidins in sea buckthorn (Hippophaë rhamnoides L.) berries of different origins with special reference to the influence of genetic background and growth location. J Agric Food Chem., 2016; 64(6): 12741282. 